\title{
Lemon Grass Essential Oil does not Modulate Cancer Cells Multidrug Resistance by Citral-Its Dominant and Strongly Antimicrobial Compound
}

\author{
Jitka Viktorová ${ }^{1}{ }^{\mathbb{D}}$, Michal Stupák ${ }^{2}$, Kateřina Řehořová $^{1}$, Simona Dobiasová ${ }^{1}$, Lan Hoang ${ }^{1}$, \\ Jana Hajšlová $^{2}$, Tran Van Thanh ${ }^{3}$, Le Van Tri ${ }^{4}$, Nguyen Van Tuan ${ }^{4}$ (D) and Tomáš Ruml ${ }^{1, *}$ \\ 1 Department of Biochemistry and Microbiology UCT Prague, Faculty of Food and Biochemical Technology, \\ Technicka 3, Prague 166 28, Czech Republic; prokesoj@vscht.cz (J.V.); rehorova@vscht.cz (K.̌̌.); \\ dobiasos@vscht.cz (S.D.); hoangl@vscht.cz (L.H.) \\ 2 Department of Food Analysis and Nutrition UCT Prague, Faculty of Food and Biochemical Technology, \\ Technicka 3, Prague 166 28, Czech Republic; stupakm@vscht.cz (M.S.); hajslovj@vscht.cz (J.H.) \\ 3 Vietnam University of Traditional Medicine, No. 2-Tran Phu, Ha Dong, Hanoi 100000, Vietnam; \\ thanhtv63@gmail.com \\ 4 Vietnam Essential Oil Joint Stock Company, No. 814/3-Lang street, Dong Da, Hanoi 100000, Vietnam; \\ biotech.jsc@gmail.com (L.V.T.); tuanbiotech.jsc@gmail.com (N.V.T.) \\ * Correspondence: rumlt@vscht.cz
}

Received: 21 February 2020; Accepted: 21 April 2020; Published: 5 May 2020

\begin{abstract}
With strong antimicrobial properties, citral has been repeatedly reported to be the dominant component of lemongrass essential oil. Here, we report on a comparison of the antimicrobial and anticancer activity of citral and lemongrass essential oil. The lemongrass essential oil was prepared by the vacuum distillation of fresh Cymbopogon leaves, with a yield of $0.5 \%(w / w)$. Citral content was measured by gas chromatography/high-resolution mass spectrometry (GC-HRMS) and determined to be $63 \%$. Antimicrobial activity was tested by the broth dilution method, showing strong activity against all tested bacteria and fungi. Citral was up to 100 times more active than the lemongrass essential oil. Similarly, both citral and essential oils inhibited bacterial communication and adhesion during P. aeruginosa and S. aureus biofilm formation; however, the biofilm prevention activity of citral was significantly higher. Both the essential oil and citral disrupted the maturated P. aeruginosa biofilm with the $\mathrm{IC}_{50} 7.3 \pm 0.4$ and $0.1 \pm 0.01 \mathrm{~mL} / \mathrm{L}$, respectively. Although it may seem that the citral is the main biologically active compound of lemongrass essential oil and the accompanying components have instead antagonistic effects, we determined that the lemongrass essential oil-sensitized methicillin-resistant $S$. aureus (MRSA) and doxorubicin-resistant ovarian carcinoma cells and that this activity was not caused by citral. A $1 \mathrm{~mL} / \mathrm{L}$ dose of oil-sensitized MRSA to methicillin up to 9.6 times and a dose of $10 \mu \mathrm{L} / \mathrm{L}$-sensitized ovarian carcinoma to doxorubicin up to 1.8 times. The mode of multidrug resistance modulation could be due to P-glycoprotein efflux pump inhibition. Therefore, the natural mixture of compounds present in the lemongrass essential oil provides beneficial effects and its direct use may be preferred to its use as a template for citral isolation.
\end{abstract}

Keywords: multidrug resistance; doxorubicin; MRSA; quorum sensing; biofilm

\section{Introduction}

Cymbopogon citratus (monocotyledonous plant belonging to Poaceae family), known as lemongrass, is widely used for its characteristic lemon odor and flavor in the culinary industry [1] as a component of spices. Moreover, it is used for its curative effects in traditional and alternative medicine in Asia, Africa and Latin America. Lemongrass is usually used in the form of a concoction of the aboveground parts 
of the plant or as an essential oil. In addition to vitamins (esp. A, C, folate, niacin, $\beta$-carotene, source: USDA National Nutrient data base), C. citratus contains flavonoids, alkaloids, tannins, phenols and saponins as beneficial compounds [2]. The chemical composition of the essential oil varies depending on the geographical origin of the plant. However, the main component is always citral $(65 \%-85 \%)$, a mixture of isomers of geranial (citral a) and neral (citral b). It also contains citronellol, citronellal, limonene, linalool, nerol, etc. [3]. Lemongrass in traditional medicine is used for the treatment of colds, influenza, cough, diabetes, malaria [4], high blood pressure, high cholesterol, fever, inflammation, hypertension [5,6], dental hygiene [7], colorectal cancer [8], nervousness, toothache and sore throat [9].

The main demonstrated bioactivities are antimicrobial, anti-inflammatory, anticancer, antimutagenic and antidiabetic activities [2]. The antimicrobial activity is the most explained. Lemongrass essential oil has a nonselective activity against both Gram-negative (Escherichia coli, Klebsiella pneumoniae, Pseudomonas aeruginosa, Proteus vulgaris) and Gram-positive bacteria (Bacillus subtilis, Staphylococcus aureus), yeasts and fungi [2]. The oil was active against Cronobacter sakazakii, a food-borne pathogen associated with neonatal necrotizing enterocolitis. Its action is ascribed to decreasing quorum sensing, biofilm formation and endotoxin production [10]. The inhibition of sulfate-reducing bacteria, causing several issues in the petroleum industry, was demonstrated as well [11,12]. Recently, the inhibition of Candida albicans and Cryptococcus sp. biofilm formation and its disruption by the essential oil were published [13-15]. The activity of lemongrass oil against Aspergillus flavus was even higher than that of some synthetic fungicides, e.g., benzimidazole and diphenylamine [16]. Besides antimicrobial activity, an effect was also demonstrated against protozoa (Plasmodium sp., Leishmania sp.) $[17,18]$ and insects (Anopheles sp., Musca domestica, Aedes aegypti) [19-21]. In addition, the essential oil of lemongrass is an effective repellent [22].

Despite showing strong antimicrobial activity and potency to treat diseases of human civilization, neither the ability of lemongrass essential oil nor citral to modulate drug resistance has ever been tested. Drug resistance is a major challenge for contemporary medicine. Antibiotic resistance is currently a frequent and typical complication of the treatment of diseases or injury. The first antibiotic, penicillin, was only introduced a few years before bacteria resistant to it were isolated. Similarly, antineoplastic resistance is a major challenge for treatment and for patient survival overall. Numerous generations of compounds overcoming drug resistance in therapy have been described; however, the usage of natural compounds still looks to be the most promising [23].

Although the effects of $C$. citratus extracts and especially its essential oil are studied relatively often, there are many areas that are controversial or deserve deeper exploration. In this paper, we report on the large spectrum of antimicrobial activities resulting from the chemical composition of lemongrass essential oil. Some of the activities have been already previously identified, however, we seek to provide deeper understanding and report some new explanations and context especially in the field of drug resistance modulation.

\section{Materials and Methods}

\subsection{Chemicals}

Mueller Hinton Broth 2 (MH broth, Sigma-Aldrich, St. Louis, MO, USA), Malt extract broth (ME broth, Oxoid, Hampshire, UK), Brain Heart Infusion Broth (BHI, Sigma-Aldrich), resazurin (Sigma-Aldrich), methicillin (Sigma-Aldrich), vancomycin (Sigma-Aldrich), citral (Sigma-Aldrich), casamino acids (Sigma-Aldrich), L-arginine (Sigma-Aldrich), Pgp-Glo Assay System (Promega, Madison, WI, USA), $\mathrm{Na}_{3} \mathrm{VO}_{4}$ (Promega), Dulbecco's Modified Eagle's Medium (DMEM, Sigma-Aldrich), doxorubicin (Sigma-Aldrich). 


\subsection{Plant Material and Essential Oil Extraction}

Cymbopogon citratus (DC.) Stapf (family: Poaceae) was identified by the Viet Nam Institute of Medicinal Plants under the Ministry of Health (3 Quang Trung Str., Hoan Kiem Distr, Ha Noi, Viet Nam). The planting location was the Phu Thanh, Hung Thi and An Binh Communes, Lac Thuy District, Hoa Binh province, Mountainous North of Viet Nam. The plants were harvested during October and November 2018. The water content of the material before oil extraction was $50 \%$. The water content was determined by weighing before and after drying.

The essential oil was distilled from the above-ground part of the plant by steam distillation under vacuum (0.5 atm, Shanghai EVP Vacuum Technology, China) at a temperature of $80-90{ }^{\circ} \mathrm{C}$ for two hours. By this procedure, which was modified according to [24], $1 \mathrm{~kg}$ of essential oil was obtained from $200 \mathrm{~kg}$ of fresh leaves. The yield of oil extraction was calculated as the percentage of obtained oil weight to fresh leaves weight. Density was determined gravimetrically.

\subsection{Essential Oil Composition Screening}

For the analysis of volatile and semi-volatile compounds in the lemongrass essential oil, gas chromatography coupled to high-resolution mass spectrometry (GC-HRMS) was employed as previously described by [25].

\subsubsection{Sample Preparation}

Fifty grams of the lemongrass essential oil was weighted into a $15 \mathrm{~mL}$ polypropylene centrifuge tube and $10 \mathrm{~mL}$ of ethyl acetate was added. One milliliter of ethyl acetate extract was diluted in $9 \mathrm{~mL}$ of isooctane. Finally, $2 \mu \mathrm{l}$ of the isooctane extract was injected into the GC-HRMS instrumentation (Agilent Technologies, Santa Clara, CA, USA).

\subsubsection{GC-HRMS}

An Agilent 7200b system consisting of an Agilent 7890B gas chromatograph equipped with a quadrupole-time of flight mass spectrometer (Q-TOF) (Agilent Technologies, Santa Clara, CA, USA) was used for the instrumental analysis.

Sample components were separated in a $30 \mathrm{~m}$ HP-5MS capillary column $(0.25 \mathrm{~mm}$ id, film thickness: $0.25 \mu \mathrm{m}$; Agilent Technologies, Santa Clara, CA, USA). The sample was injected in split mode $(1: 5)$ at $250{ }^{\circ} \mathrm{C}$ and the oven temperature was as follows: $40{ }^{\circ} \mathrm{C}(1 \mathrm{~min}), 10^{\circ} \mathrm{C} / \mathrm{min}$ to $150{ }^{\circ} \mathrm{C}$, $5{ }^{\circ} \mathrm{C} / \mathrm{min}$ to $190{ }^{\circ} \mathrm{C}, 20^{\circ} \mathrm{C} / \mathrm{min}$ to $310^{\circ} \mathrm{C}$ (hold $5 \mathrm{~min}$ ).

The mass spectrometric detector was operated in electron ionization mode and the temperature of the ion source was $230{ }^{\circ} \mathrm{C}$. The mass range was $40-550 \mathrm{~m} / \mathrm{z}$ and the resolution of the mass analyzer was set to $>12500$ (FWHM).

Volatile and semi-volatile compounds were identified and verified by NIST library 2017, isotopic pattern, exact mass (mass error $<5 \mathrm{ppm}$ ) and Kovats retention index.

\subsection{Antimicrobial Activity}

The inhibitory activity of the essential oil and citral was determined against both Gram-positive and Gram-negative bacterial strains, yeasts and micromycetes. Unless otherwise stated, microorganisms were obtained from the Collection of the Department of Biochemistry and Microbiology (DBM, UCT Prague, Prague, Czech Republic) as follows: Salmonella enterica (CCM, 4420), Proteus vulgaris (DBM, 3022), Mycobacterium smegmatis (ATCC, 70084), Pseudomonas aeruginosa (CCM, 3955), Staphylococcus aureus (ATCC, 25923), Candida famata (DBM, 23), Candida albicans (DBM, 2186), Cryptococcus albidus (DBM, 4), methicillin-resistant Staphylococcus aureus (DBM, 12). The resistant strain was obtained from the Collection of the Laboratory of Medical Microbiology (Czech Laboratory, lnc., NEM 449) and was previously characterized for its multidrug resistance properties. Unless otherwise stated, all strains are sensitive to commercial drug strains according to EUCAST (The European Committee on 
Antimicrobial Susceptibility Testing. Breakpoint tables for interpretation of MICs and zone diameters. Version 10.0, 2020).

Antibacterial and anti-yeast activity was evaluated by the standard broth-dilution method using 96-well plates and MH broth or ME broth. Overnight microbial culture was diluted to a turbidity equal to $0.5 \mathrm{McF}$ arland. After that, the standard broth microdilution method recommended by EUCAST (The European Committee on Antimicrobial Susceptibility Testing. Breakpoint tables for interpretation of MICs and zone diameters. Version 10.0,2020) was used. The essential oil and citral were diluted with the prepared microbial culture. Subsequent binary dilution provided the range of tested concentrations from 5 to $10,000 \mu \mathrm{L} / \mathrm{L}$. The positive control was the suspension of microorganisms without essential oil. Plates were incubated for $24 \mathrm{~h}$ at 37 or $28^{\circ} \mathrm{C}$ after that, absorbance $(500 \mathrm{~nm})$ was recorded using a SpectraMax i3x Multi-Mode Detection Platform (Molecular Devices, San Jose, CA, USA). The turbidity of each strain was measured in eight replicates. The turbidity of the methicillin-resistant $S$. aureus was measured in eight replicates, both with and without chloramphenicol $(0.2-200 \mathrm{mg} / \mathrm{L})$, and both with and without lemongrass essential oil.

\subsection{Anti-Biofilm Activity}

The effect of lemongrass essential oil and citral on the bacterial biofilm was tested on Staphylococcus aureus (ATCC, 25923) and Pseudomonas aeruginosa (CCM, 3955). A static anti-biofilm assay was performed in 96-well polystyrene plates, as described previously with some modifications [26]. Both samples were evaluated for their activity in two main stages (i) planktonic cell adhesion and (ii) mature biofilm disruption. The overnight culture of the tested organism was diluted with BHI broth to obtain a turbidity equal to $0.5 \mathrm{McFarland}$, and $100 \mu \mathrm{l}$ of the suspension was pipetted into each well. In the cell adhesion assay, the viability of adhered cells was evaluated by resazurin assay immediately after $24 \mathrm{~h}$ of incubation in the presence of the tested compounds at $37^{\circ} \mathrm{C}$ and triple washing with PBS (pH 7.4). In the disruption of mature biofilm assay, fresh BHI medium containing various concentrations of lemongrass or citral was added to wells with a pre-formed biofilm. After $24 \mathrm{~h}$ of incubation, the medium was removed, the wells were washed three times with PBS and $100 \mu \mathrm{L}$ of resazurin in PBS $(0.03 \mathrm{mg} / \mathrm{L})$ was added. The viability was evaluated by measuring fluorescence (560/590 nm, ex./em.) using a SpectraMax i3x Multi-Mode Detection Platform (Molecular Devices, USA). Each experiment was done in 16 repetitions.

\subsection{Anti-Quorum Sensing Activity}

For the evaluation of anti- quorum sensing activity, two commercial (ATCC) strains of Vibrio campbellii were used - BAA1118 and BAA1119 [27]. The bacteria were cultivated in Autoinducer Bioassay (AB-A) medium as described previously by [28]. The overnight culture was diluted with AB-A medium to a cell density of approximately $1 \times 10^{4} \mathrm{CFU} / \mathrm{mL}$. The binary dilution of citral and lemongrass oil $(0.1 \mu \mathrm{L} / \mathrm{L}-6 \mathrm{~mL} / \mathrm{L})$ was tested using Vibrio campbellii in a 96-well plate and after $24 \mathrm{~h}$, the cell viability was determined by resazurin assay. $\mathrm{IC}_{10}$ was chosen for the subsequent experiment. The lemongrass essential oil or citral were applied at the $\mathrm{IC}_{10}$ concentration and further binary diluted with diluted cell culture. After that, the luminescence was recorded for $24 \mathrm{~h}$ with a measurement step of 20 min using a microplate reader (SpectraMax i3 Multi-Mode Detection Platform, Molecular Devices, San Jose, CA, USA) set to $30^{\circ} \mathrm{C}$; integration time of $10,000 \mathrm{~ms}$; shaking for $60 \mathrm{~s}$ prior to measurement. The sum of luminescence was calculated and used for the determination of $\mathrm{EC}_{50}$. 


\subsection{Inhibition of Transmembrane Efflux Pump}

The inhibition of P-glycoprotein (P-gp) was tested using the in vitro Pgp-Glo Assay System according to the standard procedure [29] with only slight modification of time incubation. The incubation was prolonged in our case to $60 \mathrm{~min}$. The luminescence ( $\triangle R L U$ samples) was calculated as the difference between the relative luminescence of $\mathrm{Na}_{3} \mathrm{VO}_{4}$ and that of the samples. Orthovanadate was used as a known inhibitor of P-gp, Verapamil was used as a known activator of P-gp.

\subsection{Sensitization of Doxorubicin-Resistant Human Ovarian Carcinoma}

A human ovarian carcinoma cell line (HOC, A2780) and its doxorubicin-resistant sub-line (HOC/DOX, A2780/ADR) were purchased from Sigma-Aldrich (USA). Both cell lines were cultivated as described previously [29]. For the experiment, $1 \times 10^{5}$ cells $/ \mathrm{mL}$ were seeded into the 96 -well plates. After $24 \mathrm{~h}$, the cells were washed $3 \times$ with PBS and fresh DMEM supplemented with lemongrass essential oil $(10 \mu \mathrm{L} / \mathrm{L})$ was added. Doxorubicin in the concentration range of $0.3-80 \mu \mathrm{M}$ was then applied. The cell viability was evaluated after $72 \mathrm{~h}$ by resazurin assay as described previously [30]. The fold change was calculated as the ratio of $\mathrm{IC}_{50}$ for doxorubicin and $\mathrm{IC}_{50}$ for the doxorubicin co-treated with the lemongrass essential oil.

\subsection{Data Processing and Statistical Analysis}

The experiment was done with the appropriate number (n) of repetitions. The relative activity was evaluated as a percentage according to the formula: $100^{*}$ (slope of sample fluorescence-average slope of PC)/(average slope of NC-average slope of PC). As the positive control (PC), non-treated reaction was used. As the negative control $(\mathrm{NC})$, the blank reaction was used. $\mathrm{IC}_{50}$ values were determined using the software GraphPad Prism 7 and its function of nonlinear regression $(\mathrm{Y}=$ Bottom $+($ Top-Bottom $) /\left(1+10^{\wedge}\left((\operatorname{LogIC}-X)^{*}\right.\right.$ HillSlope $\left.)\right)$. MIC was determined as $\mathrm{IC}_{90}$ using an online tool freely provided by AAT BioQuest. The data are presented as the averages of the repetitions with the standard error of the mean (SEM). Statistical significance was checked with the Excel t-test function (two-tailed distribution, heteroscedastic type). One-way analysis of variance (ANOVA) was used followed by Duncan's post hoc test $(P<0.05)$ to show the differences between the groups. For ANOVA, the software Statistica version 12 was used (Tibco Software Inc., Palo Alto, CA, USA).

\section{Results}

The Cymbopogon citratus essential oil was obtained by vacuum steam distillation at $80-90^{\circ} \mathrm{C}$. The procedure yielded $0.5 \%(w / w)$ of the oil with the density $0.891+0.004 \mathrm{~g} / \mathrm{mL}$.

\subsection{Essential Oil Composition Screening}

The composition of the essential oil (volatile and semi-volatile compounds) was characterized by GC-HRMS. To characterize the relative abundance of volatile components in the sample, deconvolution of all compounds was performed, and the detected compounds were normalized by percent of total peaks area (Figure 1). The compounds occurring at a level higher than $1 \%$ were identified. The most dominant components in the sample were as follows: two stereoisomers of citral (geranial and neral) $>>$ geraniol-myrcene $>\gamma$-selinene $>$ terpineol-1-geranyl acetate $>\beta$-caryophyllene $>$ linalool $>$ $\alpha$-humulene $>$ nerol $>$ eucalyptol. The repeatability of the method, expressed as a relative standard deviation (RSD), was determined by the analysis of the oil sample in six repetitions, and ranged from $1.5 \%$ to $5.5 \%$ in all analyses. 


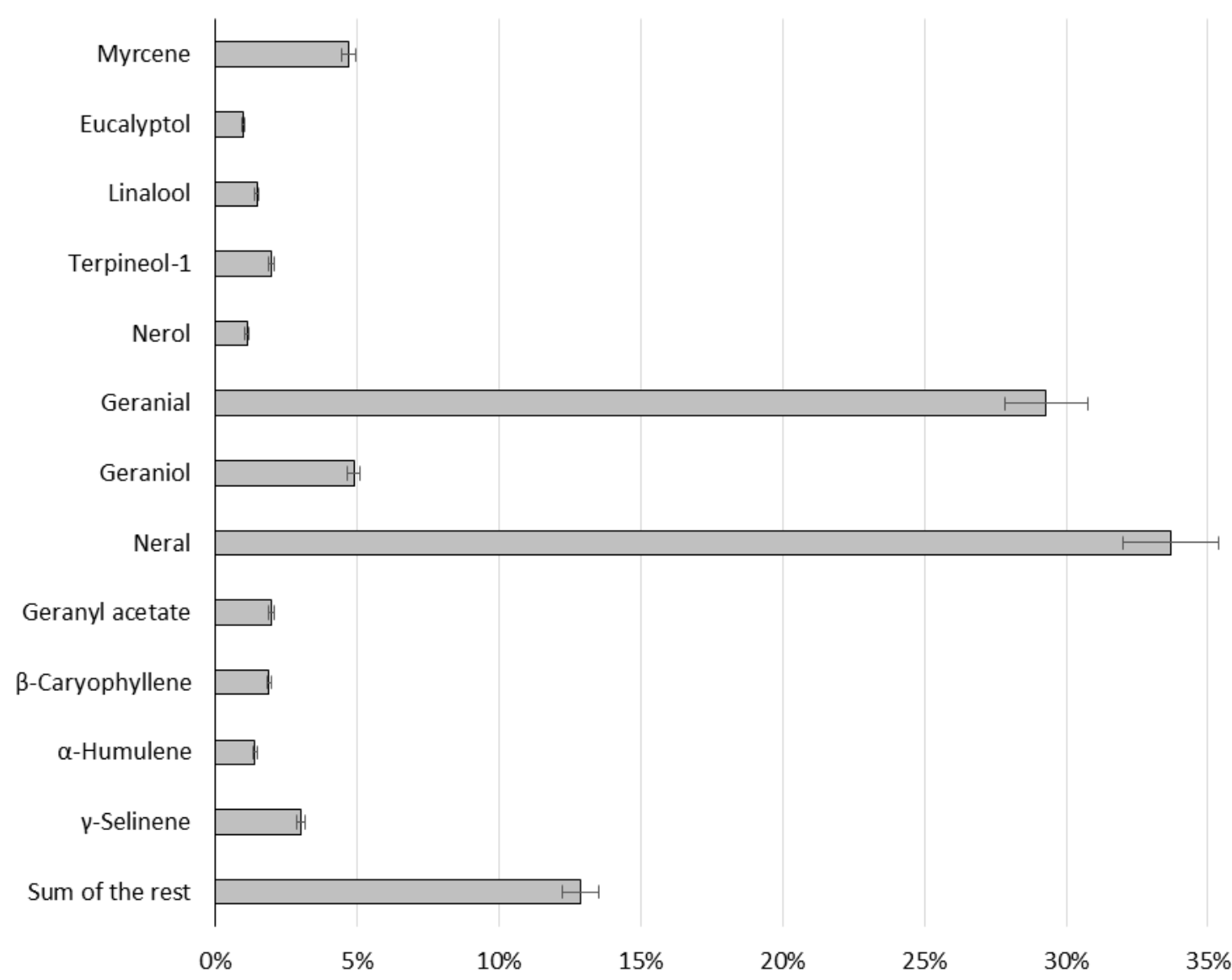

Figure 1. Chemical composition (\%) of essential oil determined by GC-HRMS. Data are presented as an average of six repetitions $(n) \pm$ relative standard deviation (RSD).

\subsection{Antimicrobial Activity}

The antimicrobial activity of lemongrass essential oil was previously published with a special focus on its strong antifungal activity. In this paper, we summarize the spectrum of its antimicrobial activity, taking into account both Gram-positive and Gram-negative bacteria and yeasts (Table 1). In agreement with previous papers, its antifungal activity was higher than its antibacterial activity. The essential oil was the most active against $C$. albidus, which could cause ocular and systematic diseases in immunosuppressed patients and against other human/animal (C. famata, C. albicans) fungal pathogens, with an $\mathrm{IC}_{50}$ in the concentration range of $180-570 \mu \mathrm{L} / \mathrm{L}$. This antibacterial activity was shown against both Gram-positive and Gram-negative bacteria. The essential oil was also active against M. smegmatis, the model organism for studies of $M$. tuberculosis and other mycobacterial pathogens. Among the tested organisms, the lowest activity was determined against the Gram-negative bacteria P. aeruginosa and S. enterica with an $\mathrm{IC}_{50}$ equal to $2.4-2.6 \mathrm{~mL} / \mathrm{L}$ and an MIC of almost double that. In comparison to lemongrass essential oil, citral-the dominant oil component, exhibited an $\mathrm{IC}_{50}$ that was several times lower with no antimicrobial specificity. In contrast to the oil, it effectively inhibited the growth of both types of bacteria and yeast in the same concentration range. Similar to the oil, citral was the most active against $C$. albidus; however, its $\mathrm{IC}_{50}$ was $100 \times$ lower than the $\mathrm{IC}_{50}$ of the oil. Similar results were observed for the other tested microorganisms, showing that citral is the main antimicrobial agent of oil and that its activity is antagonistically modulated by the accompanying components. 
Table 1. Antimicrobial activity of lemongrass essential oil.

\begin{tabular}{|c|c|c|c|c|c|}
\hline \multirow[b]{2}{*}{ species } & \multirow[b]{2}{*}{ Classification } & \multicolumn{2}{|c|}{ Lemongrass Essential Oil } & \multicolumn{2}{|c|}{ Citral } \\
\hline & & $\mathrm{IC}_{50}[\mu \mathrm{L} / \mathrm{L}]$ & $\operatorname{MIC}[\mu \mathrm{L} / \mathrm{L}]$ & $\mathrm{IC}_{50}[\mu \mathrm{L} / \mathrm{L}]$ & $\mathrm{MIC}[\mu \mathrm{L} / \mathrm{L}]$ \\
\hline Candida famata & Fungi, Ascomycota & $177 \pm 19^{\mathrm{a}}$ & $3684 \pm 271^{c, d}$ & $37 \pm 7^{b}$ & $142 \pm 19^{b, c}$ \\
\hline Cryptococcus albidus & Fungi, Basidiomycota & $199 \pm 25^{a}$ & $265 \pm 31^{a}$ & $2 \pm 0^{a}$ & $20 \pm 6^{a}$ \\
\hline Candida albicans & Fungi, Ascomycota & $571 \pm 109^{a, b}$ & $2734 \pm 250 \mathrm{~b}, \mathrm{c}$ & $83 \pm 8^{\mathrm{d}, \mathrm{e}}$ & $110 \pm 15^{b, c}$ \\
\hline Mycobacterium smegmatis & Bacteria, Gram positive & $860 \pm 89^{b}$ & $3409 \pm 775^{c, d}$ & $109 \pm 12^{\mathrm{e}}$ & $137 \pm 19^{b, c}$ \\
\hline Proteus vulgaris & Bacteria, Gram negative & $992 \pm 37^{b}$ & $1453 \pm 40^{\mathrm{a}, \mathrm{b}}$ & $97 \pm 12^{\mathrm{e}}$ & $163 \pm 34^{c}$ \\
\hline Staphylococcus aureus & Bacteria, Gram positive & $1841 \pm 199^{c}$ & $5830 \pm 198^{\mathrm{e}}$ & $77 \pm 2^{\mathrm{e}}$ & $92 \pm 2^{b, c}$ \\
\hline Pseudomonas aeruginosa & Bacteria, Gram negative & $2385 \pm 162^{d}$ & $5308 \pm 339^{e}$ & $41 \pm 2^{b}$ & $93 \pm 8^{b}$ \\
\hline Salmonella enterica & Bacteria, Gram negative & $2626 \pm 301^{d}$ & $4693 \pm 634^{\mathrm{d}, \mathrm{e}}$ & $66 \pm 8^{c, d}$ & $97 \pm 3^{b, c}$ \\
\hline
\end{tabular}

The data are presented as an average of eight repetitions $(n) \pm$ standard error of the mean (SEM). The data were analyzed by one-way ANOVA with Duncan's post hoc test $(P>0.05)$ as indicated by the superscript letters. The letters indicate the differences between the groups within one assay. Statistically significant levels are denoted with different letters. The data are presented as the concentration $(\mu \mathrm{M})$ that (i) halved the cell viability $\left(\mathrm{IC}_{50}\right)$ or (ii) reduced $90 \%$ of cell viability (MIC).

The antimicrobial activity of the essential oil was also tested against antibiotic-resistant bacteria. The clinical isolate of methicillin-resistant S. aureus (MRSA) used in this study was characterized as multidrug-resistant to a broad spectrum of antibiotics (data not shown). The $\mathrm{IC}_{50}$ concentration of chloramphenicol for MRSA was $142 \mathrm{mg} / \mathrm{L}$. To evaluate the MDR-modulating activity, MRSA was cultivated in the presence of lemongrass essential oil $(1000 \mu \mathrm{L} / \mathrm{L})$ or citral $(400 \mu \mathrm{L} / \mathrm{L})$ and chloramphenicol. Even though the citral content in the oil is $63 \%$, this concentration $(630 \mu \mathrm{L} / \mathrm{L})$ was not applied because of the high toxicity of pure citral to the cells, as shown above for drug-sensitive S. aureus $\left(\mathrm{IC}_{50} 77 \mu \mathrm{L} / \mathrm{L}\right.$ ). Therefore, we chose concentrations of lemongrass essential oil or citral equal to $\mathrm{IC}_{10}$, which were applied simultaneously with chloramphenicol to determine the $\mathrm{IC}_{50}$ of the mixture (Table 2). The addition of lemongrass oil reduced the $\mathrm{IC}_{50}$ of MRSA almost tenfold (to $15 \mathrm{mg} / \mathrm{L}$ ). The effect of citral on MRSA was almost three times lower, the sensitization of MRSA was only 3-fold.

Table 2. Sensitization of methicillin-resistant Staphylococcus aureus (MRSA) by lemongrass essential oil and citral.

\begin{tabular}{|c|c|c|c|}
\hline & $\begin{array}{c}\text { Chloramphenicol } \mathrm{IC}_{50} \\
{[\mathrm{mg} / \mathrm{L}]}\end{array}$ & $\begin{array}{c}\text { Chloramphenicol } \mathrm{IC}_{50}[\mathrm{mg} / \mathrm{L}] \\
\text { Affected by Lemongrass } \\
\text { Essential Oil }[1000 \mu \mathrm{L} / \mathrm{L}]\end{array}$ & $\begin{array}{l}\text { Chloramphenicol } \mathrm{IC}_{50}[\mathrm{mg} / \mathrm{L}] \\
\text { Affected by Citral }[400 \mu \mathrm{L} / \mathrm{L}]\end{array}$ \\
\hline MRSA & $142 \pm 10$ & $15 \pm 2$ & $42 \pm 1$ \\
\hline & Fold & $9.6 \pm 1.9$ & $3.4 \pm 0.3$ \\
\hline
\end{tabular}

The data are presented as an average of eight repetitions $(n) \pm$ standard error of the mean (SEM).

\subsection{Anti-Biofilm Activity}

Biofilm formation plays a crucial role in many medical and industrial applications. Typically, the effect of anti-biofilm compounds can be seen in two main stages: a) adhesion of the planktonic cells to the surface and b) disruption of a maturated biofilm. Both citral and lemongrass essential oil inhibited the adhesion of Gram-positive (S. aureus) and Gram-negative (P. aeruginosa) bacteria in a dose-dependent manner. In contrast to direct antimicrobial activity, a higher effect was observed for the adhesion of P. aeruginosa than for S. aureus (Figure 2). In the eradication of mature biofilms, just only citral disrupted bacterial biofilms in concentration-dependent manner with significantly higher effect on gram negative bacteria (P. aeruginosa) while lemon grass essential oil was not considered significant (Figure 3). Both citral and lemongrass essential oil disrupted the biofilm in a concentration-dependent manner with a significantly higher effect on Gram-negative bacteria (P. aeruginosa). 

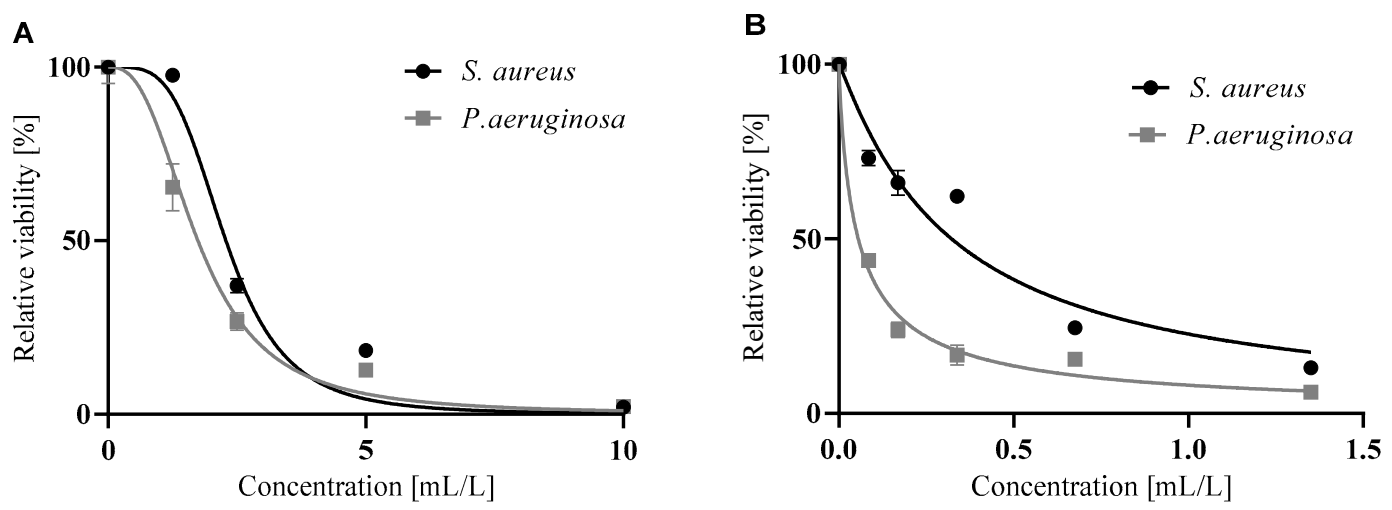

Figure 2. Inhibition of adhesion of bacteria forming a biofilm by lemongrass essential oil (A) and citral (B). The data are presented as an average of 16 repetitions with SEM.
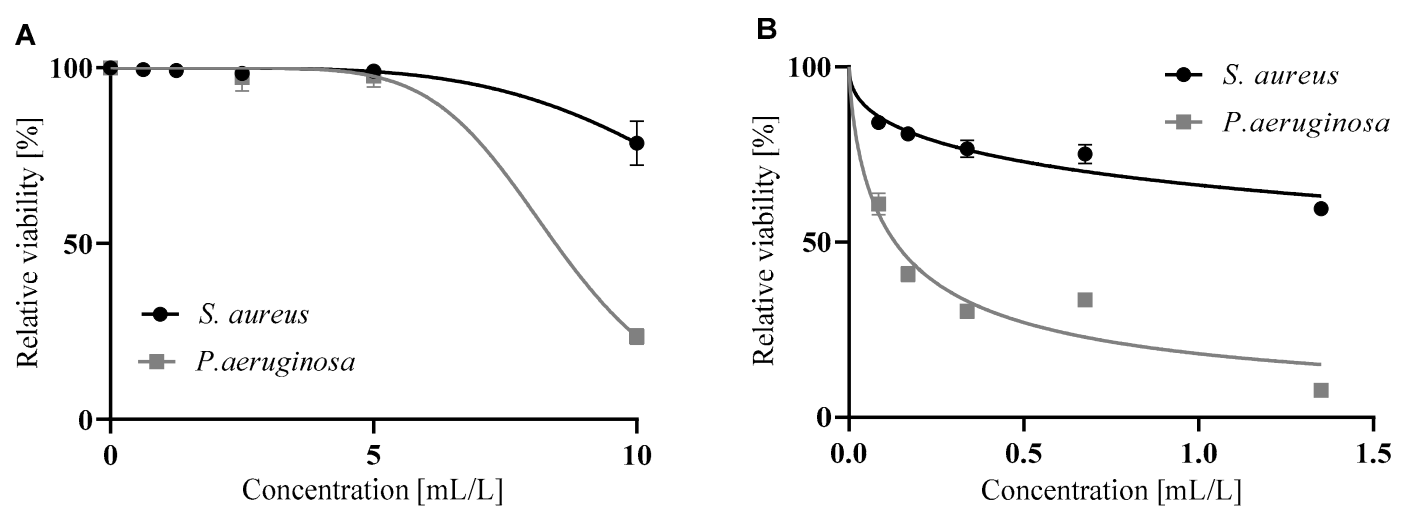

Figure 3. Disruption of maturated biofilm by lemongrass essential oil (A) and citral (B). The data are presented as an average of 16 repetitions with SEM.

As can be seen from Table 3, which compares the concentrations of citral and lemongrass essential oil that halve the respective activity, citral was more active against both phases of biofilm formation-adhering and maturated cells. As the $\mathrm{IC}_{50}$ values of citral were 7-70 $\times$ lower than the $\mathrm{IC}_{50}$ of lemongrass essential oil, it could be concluded that citral is responsible for the main activity of the essential oil against a biofilm. However, this activity is negated by the antagonistic effect of some other compounds that are also in the oil. Citral is up to $5 \times$ more active against the adhesion phase of P. aeruginosa biofilm than against an $S$. aureus biofilm.

Table 3. Concentration of citral and lemongrass essential oil that halves the respective activity: (i) adhesion of bacteria forming biofilm and (ii) mature biofilm.

\begin{tabular}{ccccc}
\hline & \multicolumn{2}{c}{ Anti-adhesion $\mathrm{IC}_{\mathbf{5 0}}[\mathrm{mL} / \mathrm{L}]$} & \multicolumn{2}{c}{ Anti-biofilm $\mathrm{IC}_{\mathbf{5 0}}[\mathrm{mL} / \mathrm{L}]$} \\
\cline { 2 - 5 } & S. aureus & P. aeruginosa & S. aureus & P. aeruginosa \\
\hline Citral & $0.32 \pm 0.03$ & $0.06 \pm 0.01$ & $>1.5$ & $0.11 \pm 0.01$ \\
\hline Lemongrass essential oil & $2.16 \pm 0.11$ & $1.90 \pm 0.20$ & $>10$ & $7.34 \pm 0.40$ \\
\hline \multicolumn{2}{c}{ Data are presented as an average of 16 repetitions with SEM. }
\end{tabular}

\subsection{Inhibition of Bacterial Cell-To-Cell Communication}

The inhibition of bacterial quorum sensing was measured by using the sensor system of $V$. campbellii. First, the direct toxicity of the oil and citral was determined in order to avoid false-positive results. Table 4 shows the concentrations of citral and lemongrass essential oil that halved the bacterial quorum sensing and viability of mutant sensor strains of $V$. campbellii, which responds either only to (i) AI-1 
autoinducer (BAA1118) or (ii) AI-2 autoinducer (BAA1119). As can be seen from the table, the concentrations that halve viability $[\mathrm{mL} / \mathrm{L}]$ and those that halved communication $[\mu \mathrm{L} / \mathrm{L}]$ differ by a factor of 1000. The decrease in luminescence was therefore caused by an inhibition of communication rather than inhibition of cell growth (Figure 4). The lemongrass essential oil inhibited communication based on both autoinducer 1 (AI-1) and autoinducer 2 (AI-2) systems similarly to citral. However, in comparison to the oil, citral effectively inhibited both systems, with a slightly higher activity for the first one. Although the oil inhibited the AI-2-mediated communication, which is based on boron compounds and used by many Gram-negative and Gram-positive bacteria, its activity was significantly higher against AI-1, which is based on homoserine lactones used by Gram-negative bacteria.

Table 4. The effect of citral and lemongrass essential oil on the quorum sensing and viability of Vibrio campbellii.

\begin{tabular}{|c|c|c|c|c|c|c|}
\hline & \multicolumn{3}{|c|}{ V. campbellii BAA1118 } & \multicolumn{3}{|c|}{ V. campbellii BAA1119 } \\
\hline & \multicolumn{2}{|c|}{ Viability $[\mathrm{mL} / \mathrm{L}]$} & \multirow{2}{*}{$\mathrm{QS} \mathrm{IC}_{50}[\mu \mathrm{L} / \mathrm{L}]$} & \multicolumn{2}{|c|}{ Viability $[\mathrm{mL} / \mathrm{L}]$} & \multirow{2}{*}{$\mathrm{QS} \mathrm{IC} \mathrm{C}_{50}[\mu \mathrm{L} / \mathrm{L}]$} \\
\hline & $\mathrm{IC}_{50}$ & $\mathrm{IC}_{10}$ & & $\mathrm{IC}_{50}$ & $\mathrm{IC}_{10}$ & \\
\hline citral & $0.24 \pm 0.11$ & $0.09 \pm 0.05$ & $0.26 \pm 0.03$ & $0.99 \pm 0.04$ & $0.68 \pm 0.08$ & $1.7 \pm 0.8$ \\
\hline lemongrass essential oil & $0.17 \pm 0.01$ & $0.05 \pm 0.01$ & $1.4 \pm 0.03$ & $5.42 \pm 0.09$ & $4.07 \pm 0.16$ & $259 \pm 88$ \\
\hline
\end{tabular}
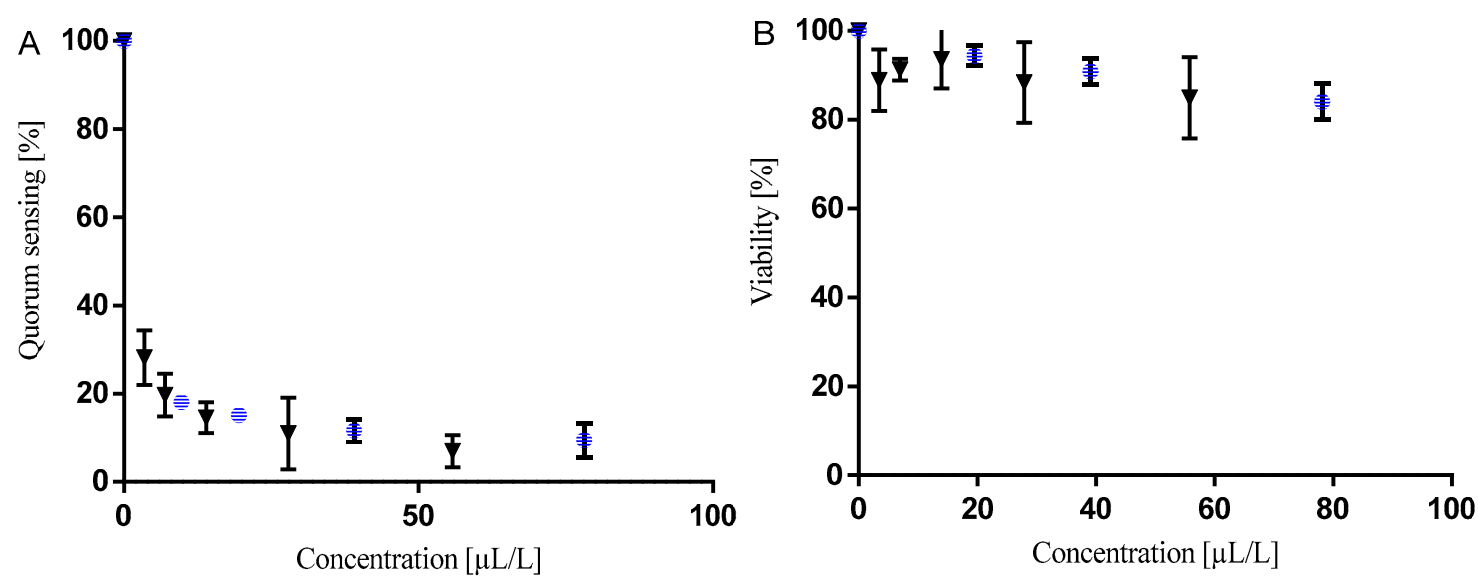

Figure 4. Dose-dependent effect of lemongrass essential oil (blue circle) and citral (black triangle) on $V$. campbellii BAA1118: (A) quorum sensing inhibition, (B) cell viability. The data are presented as an average of 3 repetitions with SEM.

\subsection{Modulation of MDR in Cancer Cells}

As was shown with the bacteria, lemongrass essential oil affected the multidrug resistance phenotype of MRSA. One of the main mechanisms involved in both bacteria and cancer drug-resistance is the overexpression of transmembrane efflux pumps, which transport the drug outside the cells and thus decrease its intracellular concentration [23]. Therefore, the activity of both citral and lemongrass essential oil was tested on a fraction of isolated membranes containing human P-glycoprotein (P-gp) - a transmembrane efflux pump responsible for most multidrug resistance phenotypes in tumors. As can be seen from Figure 5, lemongrass essential oil inhibited this pump. The function of P-gp is connected to the ATP consumption; therefore, the better the inhibitor, the lower the amount of consumed ATP. Compared with lemongrass essential oil, citral was unable to inhibit this pump even at higher concentration levels. Rather than being an inhibitor, citral was potentially the substrate of this pump, showing the typical trend, i.e., the higher the concentration, the higher the amount of consumed ATP. 


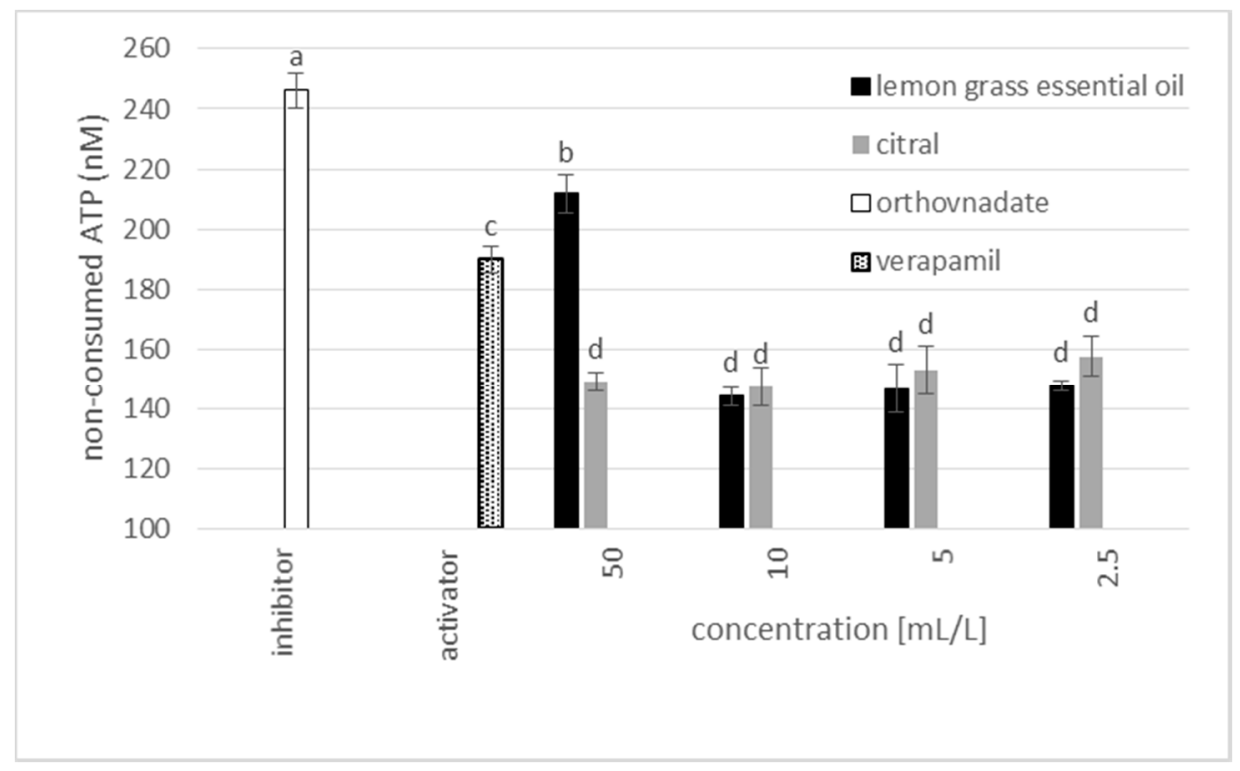

Figure 5. P-glycoprotein activity modulation. Orthovanadate was used as a known inhibitor of P-gp, Verapamil was used as a known activator of P-gp.

P-glycoprotein activity inhibition was determined as the amount of ATP which was not consumed during the efflux pump activation in comparison to the control. Orthovanadate (white columns), a known inhibitor of P-gp, was used as a positive control, verapamil (dotted columns) was used as known activator and lemongrass essential oil (black columns) and citral (gray columns) were tested in the concentration range $2.5-50 \mathrm{~mL} / \mathrm{L}$. Data are presented as an average of 3 repetitions (n) with SEM. Data were analyzed by one-way ANOVA with Duncan's post hoc test $(P>0.05)$ as indicated by the superscript letters. Statistically significant levels were denoted with different letters.

The activity of both the oil and citral were tested on an ovarian cancer cell line resistant to doxorubicin. As predicted based on the P-gp inhibition results, citral exhibited no potential to modulate the resistant phenotype of this cell line. In contrast, the co-administration of doxorubicin with the oil at a concentration far below the $\mathrm{IC}_{50}$ significantly decreased the cell viability (Figure 6).

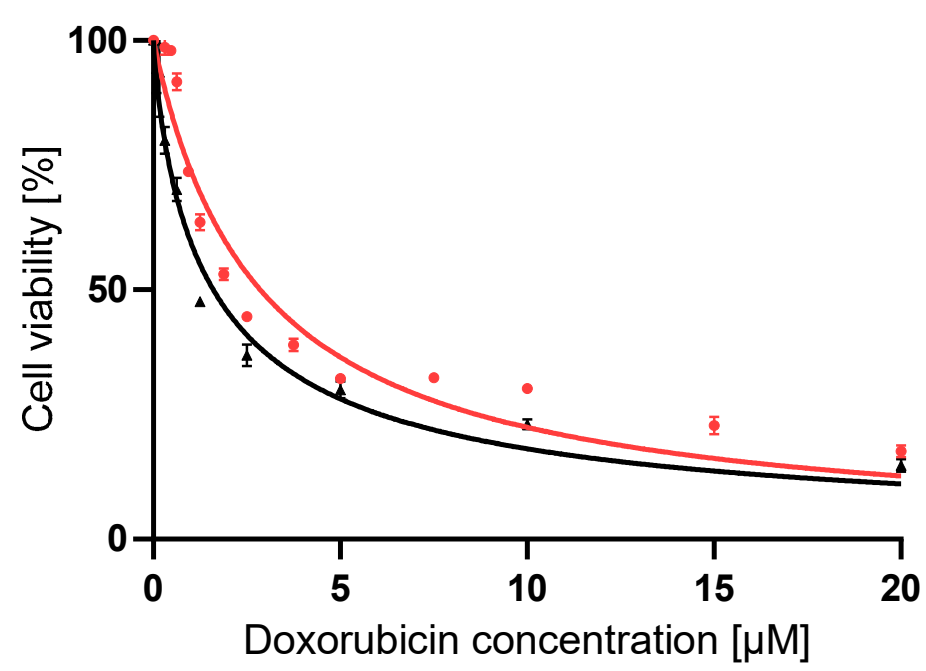

Figure 6. Inhibition of human ovarian carcinoma viability by doxorubicin (red line) and doxorubicin with lemongrass essential oil ( $10 \mu \mathrm{L} / \mathrm{L}$, black line) after $72 \mathrm{~h}$.

The sensitization of doxorubicin-resistant ovarian carcinoma was determined as the ratio of doxorubicin concentration needed to halve the cell viability with and without lemongrass essential oil 
(Table 5). The resistant cell line treated with lemongrass essential oil was almost twice as sensitive as without oil, with the $\mathrm{p}$ value of the $\mathrm{t}$-test being 0.022 . As can be seen from the table, the resistant cell line is more than $100 \times$ more resistant than the sensitive line. The chosen dose of lemongrass was non-toxic even for the sensitive cancer cell line (note: viability $86 \% \pm 4 \%$ ); therefore, the sensitization effect was not caused by a direct cytotoxicity of the oil. Citral at the same concentration level $(10 \mu \mathrm{L} / \mathrm{L}) \mathrm{did}$ not modulate the resistant phenotype and its presence did not affect the values of doxorubicin's $\mathrm{IC}_{50}$.

Table 5. Modulation of resistance to doxorubicin by lemongrass essential oil. The table shows the concentrations of doxorubicin that halved the viability of human ovarian carcinoma (HOC) cell lines in the presence of lemongrass essential oil and doxorubicin with a single-dose addition of lemongrass essential oil $(10 \mu \mathrm{L} / \mathrm{L})$. Both HOC and the same line resistant to doxorubicin (HOC/DOX) were tested.

\begin{tabular}{ccc}
\hline & HOC & HOC/DOX \\
\hline Doxorubicin, $\mathrm{IC}_{50}[\mu \mathrm{M}]$ & $0.022 \pm 0.001$ & $2.86 \pm 0.18$ \\
\hline Lemongrass, $\mathrm{IC}_{50}[\mu \mathrm{L} / \mathrm{L}]$ & $55.2 \pm 8.1$ & $197.8 \pm 5.7$ \\
\hline Doxorubicin, $\mathrm{IC}_{50}[\mu \mathrm{M}]$ with lemongrass essential oil $[10 \mu \mathrm{L} / \mathrm{L}]$ & $1.60 \pm 0.14$ \\
\hline \multicolumn{2}{c}{ Sensitization FOLD } & $1.78 \pm 0.27$ \\
\hline
\end{tabular}

The sensitization factor was calculated as the ratio of $\mathrm{IC}_{50}$ [doxorubicin, $\mu \mathrm{M}$ ] and $\mathrm{IC}_{50}$ [doxorubicin in the presence of lemongrass essential oil, $\mu \mathrm{M}]$. The data are presented as an average of 3 repetitions with SE.

\section{Discussion}

Although the promising biologic activities of both lemongrass essential oil and citral have been known for decades, their modulation of the drug-resistant phenotype has never been tested in as much depth as by this paper. Here we report on the modulation of both bacterial and cancer drug resistance by lemongrass essential oil; however, based on our results, this activity is not caused by citral. The activity of Cymbopogon flexuosus essential oil against multi-drug resistant bacteria was previously studied using Acinetobacter baumannii strains [25]. The mean value of MIC was about $0.65 \%(v / v)$. Our $\mathrm{IC}_{50}$ value for MRSA $(0.4 \%, v / v)$ agrees with published data. The sensitization factor of methicillin-resistant $S$. aureus (MRSA) by lemongrass essential oil was several times higher than the factor for citral. Therefore, the oil is more promising for modulating a bacterial drug-resistance phenotype. In addition, Berdejo et al. [31] reported on an enhanced resistance in $S$. aureus after sub-inhibitory doses of citral exposure. This was in agreement with the study of Chueca et al. [32], who published that the exposure of a hyper-resistant strain of E. coli to a sub-inhibitory concentration of citral did not increase the direct resistance globally; however, it led to the emergence of several mutants displaying an increased minimum inhibitory concentration of citral. Therefore, the application of oil as a natural component mixture is in agreement with the current trend of drug resistance treatment based on a combination of biologically active compounds with different targets.

Both lemongrass essential oil and citral possess strong antimicrobial activity, even against antibiotic-resistant strains; therefore, their activity against a biofilm was evaluated within this paper as well. The disruption of a matured biofilm was only observed for Gram-negative bacteria treated with either citral or with the oil. The application of $0.06 \mathrm{~mL} / \mathrm{L}$ of citral eliminated half of the P. aeruginosa cells adhesion, which is in agreement with the results of Espina et al., who demonstrated that the biofilm formation of resistant $S$. aureus was significantly inhibited by $0.2 \mathrm{~mL} / \mathrm{L}$ of citral [33]. Lemongrass essential oil was previously used for an oral spray preparation intended to inhibit Streptococcus sp. biofilm formation [34]. Similarly, both oil and citral prevented the biofilm formation of sulfate-reducing bacteria [12]. Both papers are in agreement with our results, which show that relatively low citral doses of 61 and $323 \mathrm{ppm}$ inhibit the adhesion of both Gram-negative and positive bacteria by $50 \%$, respectively. Lemongrass essential oil inhibited the adhesion of both cell types as well, however at several times higher concentrations. In another study, $0.2 \mu \mathrm{g} / \mathrm{mL}$ of citral significantly inhibited mixed biofilm (S. aureus and S. enterica) formation, which could be caused by decreasing AI-2-mediated 
quorum sensing communication [35]. The inhibition of AI-2 production by citral treatment was demonstrated by [36]. Our results also proved that citral significantly inhibited both biofilm formation and bacterial communication via AI-2; however, the inhibition of quorum sensing based on AI-1 was more effective and to our knowledge, this is the first report on such activity.

The potential of citral to interact with transmembrane efflux pumps has not been satisfactorily explained yet. It was previously shown that citral acts neither as a P-gp inhibitor (ABCB1) nor as a multidrug resistance protein 1 and 2 (MRP1, ABCC1; MRP2, ABCC2) inhibitor [37-39]. Moreover, citral should not affect ATPase activity in any of these pumps [38]. On the other hand, Queiroz et al. [40] observed that citral downmodulated the activity and inhibited the expression of multidrug resistance associated protein 1 (MRP1). In contrast to lemongrass essential oil, citral up to a concentration of $50 \mathrm{~mL} / \mathrm{L}$ was unable to inhibit pure P-gp in the in vitro system and did not affect the DOX sensitivity of doxorubicin-resistant ovarian carcinoma over $72 \mathrm{~h}$ of incubation. The resistance of the cell line is caused by P-gp overexpression [29]. Therefore, the $10-\mu \mathrm{L} / \mathrm{L}$ dose of citral should not affect the expression level of P-gp, as the cells preserved the drug-resistant phenotype. As in bacteria, the lemongrass essential oil, being a natural mixture of biologically active compounds, is more promising in overcoming drug resistance in eukaryotic cells.

The antimicrobial activity of both lemongrass essential oil and citral have been reported many times before, but here we compared the activity of the same essential oil and pure citral against prokaryotic and eukaryotic organisms, i.e., Gram-positive, Gram-negative bacteria and yeasts, respectively. Despite the similarity of some of our results with published data, we found some differences, e.g., in the minimal oil concentration inhibiting C. albicans (MIC), which was published as $288 \mathrm{mg}$ of oil per liter [41]. Our determination of the MIC for C. albicans gave $2734 \mu \mathrm{L} / \mathrm{L}$, which corresponds to an MIC of $2435 \mathrm{mg}$ of oil per liter (recalculated based on the gravimetrically defined density of our oil as 0.891 $\pm 0.004 \mathrm{~g} / \mathrm{mL}$ ). The difference could be explained by the different sensitivity of yeast strains. The same reasons may apply for differences between our MIC of $C$. albicans, which about 14 times higher than that obtained by Sacchetti et al. [42].

The antimicrobial activity of citral was previously measured for E. coli. The determined value ( $\geq 0.01 \%$ ) [43] corresponds to our observation for Gram-negative bacteria (41-97 $\mu \mathrm{L} / \mathrm{L})$. Similar to our results, Gupta et al. also demonstrated that citral has a stronger antimicrobial activity than lemongrass essential oil [44]. Citral was up to 10 times more active against some Acinetobacter baumannii strains than lemongrass essential oil in the study of Adukwu et al. [25].

The quality of the oil is generally assessed by its content of citral, high oxygenated monoterpenes, low monoterpene and sesquiterpene hydrocarbons, and finally low oxygenated sesquiterpenes. Our lemongrass essential oil had a standard composition comparable to previously published data. The yield of essential oil obtained by our distillation of fresh leaves was $0.5 \%(w / w)$, which corresponds to the data of other authors, who published yields of $0.6 \%$ [45] or $0.7 \%$ [46-48]. As expected, the dominant group of terpenes present in essential oil was comprised of oxygenated monoterpenes with the main components being neral (citral b, 33.7\%) and geranial (citral a, 29.3\%). The amounts of citral isomers differ in the literature, typically with a higher content of neral. The common contents are $36.2 \%$ [41], $39.5 \%$ [48], 41.3\% [42], 41.8\% [47], 42.2\% [45], 50.5\% [25], 52.9\% [34], up to 56.8\% [49] for citral a and $26.5 \%$ [41], 30.4\% [47], 32.3\% [42], 32.5\% [45], 33.1 [49], 35.5\% [48], 38.1\% [34], up to $38.5 \%$ [25] for neral. The presence of $1.5 \%$ linalool is comparable with the data published by other authors- $0.4 \%$ [49], $1.3 \%$ [42], 2.8\% [25]. The level of geraniol was also similar, which we quantified as $4.9 \%$ and other research groups as $2.2 \%-8.2 \%[25,48]$.

\section{Conclusions}

Although the antimicrobial activity of citral is to some extent negated by the accompanying components of lemongrass essential oil, these components have promising activity against antibiotic-resistant bacteria and chemotherapeutic-resistant tumors. Citral preserves its strong antimicrobial activity, resulting in direct bacterial cytotoxicity, the inhibition of quorum sensing 
and influence on cell adhesion during biofilm formation as well as disruption of a matured biofilm. Further fractionation searching for bioactive compounds modulating the drug-resistance phenotype is a promising therapeutic approach.

Author Contributions: Conceptualization, J.V., M.S. and T.R.; methodology, J.V., M.S. and T.R.; software, J.V. and M.S.; validation, J.V., M.S., K. ̌̌., S.D. and L.H.; formal analysis, J.V., M.S. and T.R.; investigation, T.V.T., L.V.T., N.V.T., J.H. and T.R.; resources, T.V.T., L.V.T., N.V.T., J.H. and T.R.; data curation, J.V., M.S., K.̌̌., S.D. and L.H.; writing—original draft preparation, J.V., T.R.; writing—review and editing, J.V., T.R., M.S. and J.H.; visualization, J.V. and M.S.; supervision, T.R. and J.H.; project administration, T.R. and J.H.; funding acquisition, T.R. and J.H. All authors have read and agreed to the published version of the manuscript.

Funding: This research was funded by the Czech Science Foundation, No 18-00150S; (ii) the European Union Horizon 2020 research and innovation Program, No 692195 ("MultiCoop"); (iii) mobility project from the Czech Ministry of Education, Youth and Sports INTER-COST LTC19007 (COST Action CA17104 STRATAGEM); (iv) the METROFOOD-CZ research infrastructure project (MEYS Grant No: LM2018100) including access to its facilities and (v) the Czech National Program of Sustainability, No LO1601.

Acknowledgments: The authors thank Ben Watson-Jones, MEng, for providing language corrections.

Conflicts of Interest: The authors declare no conflict of interest.

\section{References}

1. Ekpenyong, C.E.; Akpan, E.E. Use of Cymbopogon citratus essential oil in food preservation: Recent advances and future perspectives. Crit. Rev. Food Sci. Nutr. 2017, 57, 2541-2559. [CrossRef] [PubMed]

2. Ekpenyong, C.E.; Akpan, E.; Nyoh, A. Ethnopharmacology, phytochemistry, and biological activities of Cymbopogon citratus (dc.) stapf extracts. Chin. J. Nat. Med. 2015, 13, 321-337. [CrossRef]

3. Ganjewala, D. Cymbopogon essential oils: Chemical compositions and bioactivities. Int. J. Essent. Oil Ther. 2009, 3, 56-65.

4. Avoseh, O.; Oyedeji, O.; Rungqu, P.; Nkeh-Chungag, B.; Oyedeji, A. Cymbopogon species; ethnopharmacology, phytochemistry and the pharmacological importance. Molecules 2015, 20, 7438-7453. [CrossRef] [PubMed]

5. Bieski, I.G.; Leonti, M.; Arnason, J.T.; Ferrier, J.; Rapinski, M.; Violante, I.M.; Balogun, S.O.; Pereira, J.F.; Figueiredo Rde, C.; Lopes, C.R.; et al. Ethnobotanical study of medicinal plants by population of valley of juruena region, legal amazon, mato grosso, brazil. J. Ethnopharmacol. 2015, 173, 383-423. [CrossRef] [PubMed]

6. De Santana, B.F.; Voeks, R.A.; Funch, L.S. Ethnomedicinal survey of a maroon community in brazil's atlantic tropical forest. J. Ethnopharmacol. 2016, 181, 37-49. [CrossRef]

7. Fongnzossie, E.F.; Tize, Z.; Fogang Nde, P.J.; Nyangono Biyegue, C.F.; Bouelet Ntsama, I.S.; Dibong, S.D.; Nkongmeneck, B.A. Ethnobotany and pharmacognostic perspective of plant species used as traditional cosmetics and cosmeceuticals among the gbaya ethnic group in eastern cameroon. S. Afr. J. Bot. 2017, 112, 29-39. [CrossRef]

8. Ochwang'i, D.O.; Kimwele, C.N.; Oduma, J.A.; Gathumbi, P.K.; Mbaria, J.M.; Kiama, S.G. Medicinal plants used in treatment and management of cancer in kakamega county, kenya. J. Ethnopharmacol. 2014, 151, 1040-1055. [CrossRef]

9. Rehecho, S.; Uriarte-Pueyo, I.; Calvo, J.; Vivas, L.A.; Calvo, M.I. Ethnopharmacological survey of medicinal plants in nor-yauyos, a part of the landscape reserve nor-yauyos-cochas, peru. J. Ethnopharmacol. 2011, 133, 75-85. [CrossRef]

10. Shi, C.; Sun, Y.; Liu, Z.; Guo, D.; Sun, H.; Sun, Z.; Chen, S.; Zhang, W.; Wen, Q.; Peng, X.; et al. Inhibition of Cronobacter sakazakii virulence factors by citral. Sci. Rep. 2017, 7, 43243. [CrossRef]

11. Souza, P.M.; Goulart, F.R.V.; Marques, J.M.; Bizzo, H.R.; Blank, A.F.; Groposo, C.; Sousa, M.P.; Volaro, V.; Alviano, C.S.; Moreno, D.S.A.; et al. Growth inhibition of sulfate-reducing bacteria in produced water from the petroleum industry using essential oils. Molecules 2017, 22, 648. [CrossRef] [PubMed]

12. Korenblum, E.; Regina de Vasconcelos Goulart, F.; de Almeida Rodrigues, I.; Abreu, F.; Lins, U.; Alves, P.B.; Blank, A.F.; Valoni, E.; Sebastian, G.V.; Alviano, D.S.; et al. Antimicrobial action and anti-corrosion effect against sulfate reducing bacteria by lemongrass (Cymbopogon citratus) essential oil and its major component, the citral. AMB Express 2013, 3, 1-8. [CrossRef] [PubMed] 
13. Madeira, P.L.B.; Carvalho, L.T.; Paschoal, M.A.B.; de Sousa, E.M.; Moffa, E.B.; da Silva, M.A.D.S.; Tavarez, R.D.J.R.; Gonçalves, L.M. In vitro effects of lemongrass extract on Candida albicans biofilms, human cells viability, and denture surface. Front. Cell. Infect. Microbiol. 2016, 6, 71. [CrossRef] [PubMed]

14. Khan, M.S.; Ahmad, I. Biofilm inhibition by cymbopogon citratus and syzygium aromaticum essential oils in the strains of candida albicans. J. Ethnopharmacol. 2012, 140, 416-423. [CrossRef]

15. Kumari, P.; Mishra, R.; Arora, N.; Chatrath, A.; Gangwar, R.; Roy, P.; Prasad, R. Antifungal and anti-biofilm activity of essential oil active components against Cryptococcus neoformans and Cryptococcus laurentii. Front. Microbiol. 2017, 8, 2161. [CrossRef]

16. Singh, P.; Shukla, R.; Kumar, A.; Prakash, B.; Singh, S.; Dubey, N.K. Effect of Citrus reticulata and Cymbopogon citratus essential oils on Aspergillus flavus growth and aflatoxin production on Asparagus racemosus. Mycopathologia 2010, 170, 195-202. [CrossRef]

17. Chukwuocha, U.M.; Fernandez-Rivera, O.; Legorreta-Herrera, M. Exploring the antimalarial potential of whole Cymbopogon citratus plant therapy. J. Ethnopharmacol. 2016, 193, 517-523. [CrossRef]

18. Santos Serafim Machado, M.; Ferreira Silva, H.B.; Rios, R.; Pires de Oliveira, A.; Vilany Queiroz Carneiro, N.; Santos Costa, R.; Santos Alves, W.; Meneses Souza, F.L.; da Silva Velozo, E.; Alves de Souza, S.; et al. The anti-allergic activity of Cymbopogon citratus is mediated via inhibition of nuclear factor kappa b (nf-kappab) activation. BMC Complement. Altern. Med. 2015, 15, 168. [CrossRef]

19. Akono Ntonga, P.; Baldovini, N.; Mouray, E.; Mambu, L.; Belong, P.; Grellier, P. Activity of Ocimum basilicum, Ocimum canum, and Cymbopogon citratus essential oils against Plasmodium falciparum and mature-stage larvae of anopheles funestus s.S. Parasite 2014, 21, 33. [CrossRef]

20. Chauhan, N.; Malik, A.; Sharma, S.; Dhiman, R.C. Larvicidal potential of essential oils against Musca domestica and Anopheles stephensi. Parasitol. Res. 2016, 115, 2223-2231. [CrossRef]

21. Soonwera, M.; Phasomkusolsil, S. Effect of Cymbopogon citratus (lemongrass) and Syzygium aromaticum (clove) oils on the morphology and mortality of Aedes aegypti and Anopheles dirus larvae. Parasitol. Res. 2016, 115, 1691-1703. [CrossRef] [PubMed]

22. Baldacchino, F.; Tramut, C.; Salem, A.; Liénard, E.; Delétré, E.; Franc, M.; Martin, T.; Duvallet, G.; Jay-Robert, P. The repellency of lemongrass oil against stable flies, tested using video tracking. Parasite 2013, $20,21$. [CrossRef] [PubMed]

23. Chambers, C.S.; Viktorova, J.; Rehorova, K.; Biedermann, D.; Turkova, L.; Macek, T.; Kren, V.; Valentova, K. Defying multidrug resistance! Modulation of related transporters by flavonoids and flavonolignans. J. Agric. Food Chem. 2020, 68, 1763-1779. [CrossRef] [PubMed]

24. Mirghani, M.; Liyana, Y.; Jamal, P. Bioactivity analysis of lemongrass (Cymbopogan citratus) essential oil. Int. Food Res. J. 2012, 19, 569-575.

25. Adukwu, E.C.; Bowles, M.; Edwards-Jones, V.; Bone, H. Antimicrobial activity, cytotoxicity and chemical analysis of lemongrass essential oil (Cymbopogon flexuosus) and pure citral. Appl. Microbiol. Biotechnol. 2016, 100, 9619-9627. [CrossRef]

26. Haney, E.F.; Trimble, M.J.; Cheng, J.T.; Valle, Q.; Hancock, R.E.W. Critical assessment of methods to quantify biofilm growth and evaluate antibiofilm activity of host defence peptides. Biomolecules 2018, 8. [CrossRef]

27. Bassler, B.; Greenberg, E.; Stevens, A. Cross-species induction of luminescence in the quorum-sensing bacterium Vibrio harveyi. J. Bacteriol. 1997, 179, 4043-4045. [CrossRef]

28. Bezek, K.; Kurinčič, M.; Knauder, E.; Klančnik, A.; Raspor, P.; Bucar, F.; Smole Možina, S. Attenuation of adhesion, biofilm formation and quorum sensing of Campylobacter jejuni by Euodia ruticarpa. Phytother. Res. 2016, 30, 1527-1532. [CrossRef]

29. Viktorova, J.; Dobiasova, S.; Rehorova, K.; Biedermann, D.; Kanova, K.; Seborova, K.; Vaclavikova, R.; Valentova, K.; Ruml, T.; Kren, V.; et al. Antioxidant, anti-inflammatory, and multidrug resistance modulation activity of silychristin derivatives. Antioxidants 2019, 8. [CrossRef]

30. Riss, T.L.; Moravec, R.A.; Niles, A.L.; Duellman, S.; Benink, H.A.; Worzella, T.J.; Minor, L. Assay Guidance Manual; Sittampalam, G.S., Brimacombe, K., Grossman, A., Arkin, M., Auld, D., Austin, C.P., Baell, J., Bejcek, B., Caaveiro, J.M.M., Chung, T.D.Y., et al., Eds.; Eli Lilly \& Company and the National Center for Advancing Translational Sciences: Bethesda, MD, USA, 2013.

31. Berdejo, D.; Chueca, B.; Pagán, E.; Renzoni, A.; Kelley, W.L.; Pagán, R.; Garcia-Gonzalo, D. Sub-inhibitory doses of individual constituents of essential oils can select for Staphylococcus aureus resistant mutants. Molecules 2019, 24, 170. [CrossRef] 
32. Chueca, B.; Berdejo, D.; Gomes-Neto, N.J.; Pagan, R.; Garcia-Gonzalo, D. Emergence of hyper-resistant Escherichia coli mg1655 derivative strains after applying sub-inhibitory doses of individual constituents of essential oils. Front. Microbiol. 2016, 7, 273. [CrossRef] [PubMed]

33. Espina, L.; Pagán, R.; López, D.; García-Gonzalo, D. Individual constituents from essential oils inhibit biofilm mass production by multi-drug resistant Staphylococcus aureus. Molecules 2015, 20, 11357-11372. [CrossRef] [PubMed]

34. Mitrakul, K.; Srisatjaluk, R.; Srisukh, V.; Lomarat, P.; Vongsawan, K.; Kosanwat, T. Cymbopogon citratus (lemongrass oil) oral sprays as inhibitors of mutans Streptococci biofilm formation. J. Clin. Diagn. Res. 2018, 12, 6-12. [CrossRef]

35. Zhang, H.M.; Zhou, W.Y.; Zhang, W.Y.; Yang, A.L.; Liu, Y.L.; Jiang, Y.; Huang, S.S.; Su, J.Y. Inhibitory effects of citral, cinnamaldehyde, and tea polyphenols on mixed biofilm formation by foodborne Staphylococcus aureus and Salmonella enteritidis. J. Food Prot. 2014, 77, 927-933. [CrossRef]

36. Sun, Y.; Guo, D.; Hua, Z.; Sun, H.; Zheng, Z.; Xia, X.; Shi, C. Attenuation of multiple Vibrio parahaemolyticus virulence factors by citral. Front. Microbiol. 2019, 10, 894. [CrossRef]

37. Zhang, W.; Lim, L.-Y. Effects of spice constituents on P-glycoprotein-mediated transport and cyp3a4-mediated metabolism in vitro. Drug Metab. Dispos. 2008, 36, 1283-1290. [CrossRef]

38. Nabekura, T.; Yamaki, T.; Kitagawa, S. Effects of chemopreventive citrus phytochemicals on human P-glycoprotein and multidrug resistance protein 1. Eur. J. Pharmacol. 2008, 600, 45-49. [CrossRef]

39. Wortelboer, H.M.; Usta, M.; van Zanden, J.J.; van Bladeren, P.J.; Rietjens, I.M.; Cnubben, N.H. Inhibition of multidrug resistance proteins mrp1 and mrp2 by a series of alpha,beta-unsaturated carbonyl compounds. Biochem. Pharmacol. 2005, 69, 1879-1890. [CrossRef] [PubMed]

40. Queiroz, R.M.; Takiya, C.M.; Guimaraes, L.P.; Rocha Gda, G.; Alviano, D.S.; Blank, A.F.; Alviano, C.S.; Gattass, C.R. Apoptosis-inducing effects of Melissa officinalis 1. Essential oil in glioblastoma multiforme cells. Cancer Investig. 2014, 32, 226-235. [CrossRef]

41. Tyagi, A.K.; Malik, A. Liquid and vapour-phase antifungal activities of selected essential oils against Candida albicans: Microscopic observations and chemical characterization of Cymbopogon citratus. BMC Complement. Altern. Med. 2010, 10, 65. [CrossRef]

42. Sacchetti, G.; Maietti, S.; Muzzoli, M.; Scaglianti, M.; Manfredini, S.; Radice, M.; Bruni, R. Comparative evaluation of 11 essential oils of different origin as functional antioxidants, antiradicals and antimicrobials in foods. Food Chem. 2005, 91, 621-632. [CrossRef]

43. Onawunmi, G. Evaluation of the antimicrobial activity of citral. Lett. Appl. Microbiol. 2008, 9, $105-108$. [CrossRef]

44. Gupta, A. A study on antimicrobial activities of essential oils of different cultivars of lemongrass (Cymbopogon flexuosus). Pharm. Sci. 2016, 22, 164-169. [CrossRef]

45. Boukhatem, M.N.; Ferhat, M.A.; Kameli, A.; Saidi, F.; Kebir, H.T. Lemon grass (Cymbopogon citratus) essential oil as a potent anti-inflammatory and antifungal drugs. Libyan J. Med. 2014, 9. [CrossRef] [PubMed]

46. Mohamed Hanaa, A.R.; Sallam, Y.I.; El-Leithy, A.S.; Aly, S.E. Lemongrass (Cymbopogon citratus) essential oil as affected by drying methods. Ann. Agric. Sci. 2012, 57, 113-116. [CrossRef]

47. Saraswathi, V.; Thara Saraswathi, K.J. Evaluation of polar and non-polar fractions of essential oil from Cymbopogon citratus (dc.) stapf. Int. J. Green Herb. Chem. 2013, 2, 923-929.

48. Kpoviessi, S.; Bero, J.; Agbani, P.; Gbaguidi, F.; Kpadonou-Kpoviessi, B.; Sinsin, B.; Accrombessi, G.; Frederich, M.; Moudachirou, M.; Quetin-Leclercq, J. Chemical composition, cytotoxicity and in vitro antitrypanosomal and antiplasmodial activity of the essential oils of four Cymbopogon species from benin. J. Ethnopharmacol. 2014, 151, 652-659. [CrossRef]

49. Shaikh, M.; Suryawanshi, Y.; Mokat, D. Volatile profiling and essential oil yield of Cymbopogon citratus (dc.) stapf treated with rhizosphere fungi and some important fertilizers. J. Essent. Oil Bear. Plants 2019, 22, 1-7. [CrossRef]

(C) 2020 by the authors. Licensee MDPI, Basel, Switzerland. This article is an open access article distributed under the terms and conditions of the Creative Commons Attribution (CC BY) license (http://creativecommons.org/licenses/by/4.0/). 